\title{
無筋コンクリート海岸構造物のひび割れ幅に基 づく新しい劣化度判定基準の提案
}

\author{
古谷 宏一 1 横田 弘2・橋本 勝文3 \\ 1学生会員 北海道大学大学院 工学院（ \\ E-mail:furuya-koichi@eng.hokudai.ac.jp \\ 2フェロー 北海道大学大学院教授 工学研究院（干060-8628 札幌市北区北13条西8丁目） \\ E-mail:yokota@eng.hokudai.ac.jp \\ ${ }^{3}$ 正会員 北海道大学大学院助教 工学研究院 ( $\bar{T} 060-8628$ 札幌市北区北13条西 8 丁目) \\ E-mail:hashimoto.k@eng.hokudai.ac.jp
}

\begin{abstract}
本論文では，無筋コンクリート胸壁を対象とした現地調査からひび割れ性状に関する情報を蓄積し，確 率統計手法に基づき劣化状況を把握することにより，目視により簡易に測定できる鉛直ひび割れ幅から施 設の耐力低下に大きな影響を及ぼすと考えられるひび割れ深さを推定する式を提案した. また, 得られた 知見に基づき, ひび割れの生じた胸壁を解析モデルに置換え, ひび割れ深さ, ひび割れ本数, 構造部材の 寸法および想定する荷重を変化させた非線形有限要素解析を行い, 構造性能の低下を評価した. その結果, 劣化状態と構造性能（耐力）との関係を定量的に明らかとし, 無筋コンクリート海岸構造物の耐力低下に 基づいて，鉛直ひび割れ幅およびひび割れ本数を指標とする新しい劣化度判定基準を提案した。
\end{abstract}

Key Words : un-reinforced concrete structure, crack, FEM, structural peformance

\section{1. はじめに}

高度経済成長期に整備された多数の社会基盤施設は既 に建設後 40 年以上経過し，老朽化が年々深刻になってい る. そのため, 今後, 更新・維持補修費がますます増大 していくと予測される。一例として，高橋ら ${ }^{1)}$ の試算に よれば，2003年以降の港湾施設における全体事業費の伸 び率を-2\%と仮定した場合，2025年において，全体港湾 施設の事業費の概 $280 \%$ を更新・維持補修費が占めると 予測されている。 したがって，より低コストで，効果的 かつ効率的な維持管理手法を確立し, 必要な性能を保持 した状態で施設を長期間利用寸ることが求められる。 そ のためには，施設の保有性能評価および性能低下の将来 予測を適切に行う必要がある. 我が国のコンクリート構 造物における保有性能評価および維持管理に関する研究 は，大部分が鉄筋コンクリート構造物を対象としたもの である2,3). しかしながら，海岸構造物においては，多数 の無筋コンクリート構造物が整備されている．それにも かかわらず，無筋コンクリート構造物を対象とした検討 が希少であるため, 維持管理計画に際して, 当該施設の 保有性能評価および精度の高い性能低下の将来予測が不 十分である. さらに, 東日本大震災において, 海岸コン
クリート構造物の重要性が再認識され, 既設構造物の適 切な保有性能評価ならびに維持管理が重要であるとの提 言がなされている ${ }^{4)}$. 以上の背景の下，本研究では，無 筋コンクリート海岸構造物である胸壁を対象に, 劣化指 標となる鉛直ひび割れの発生と構造物の耐力の定量的な 関係を得ることを目的する。 これにより得られた知見に 基づき，目視検查で簡易に測定可能なひび割れ幅を指標 とし, 胸壁の構造性能（耐力）に基づく新しい劣化度判 定基準を提案する，なお，本論文では，胸壁に生じる劣 化として，性能に最も影響を与えると考えられる鉛直方 向に発生したひび割れを対象とする.

\section{2. 現地調査}

\section{(1) ひび割れ幅およびひび割れ深さの測定}

調查は，海岸構造物の胸壁を対象とし，ひび割れ幅， ひび割れ深さおよび胸壁寸法について測定を行った. 胸 壁に発生していたひび割れの例を図-1に，胸壁の外観を 図-2に示す、ひび割れ深さの測定には，衝撃弾性波法を 用いた5)、ひび割れの測定は，胸壁に作用する外力ある いはコンクリートの幹燥収縮に起因寸るものと推定され る鉛直方向のひび割れを対象とした. 各ひび割れに対し 


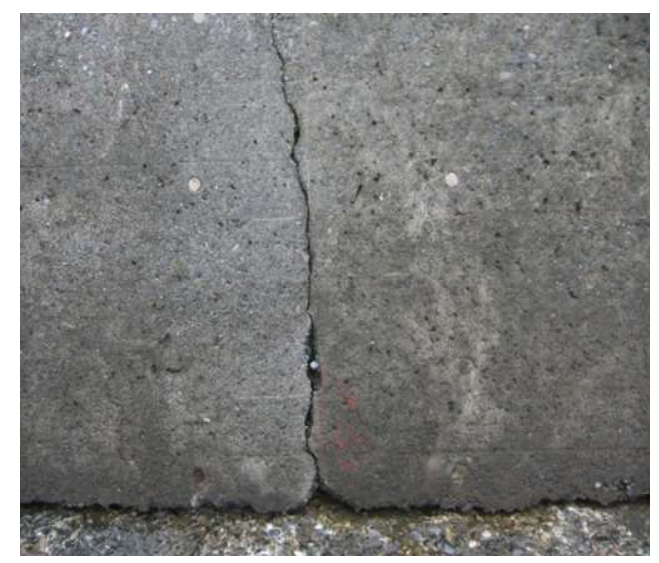

図-1 胸壁に発生したひひ割れの例

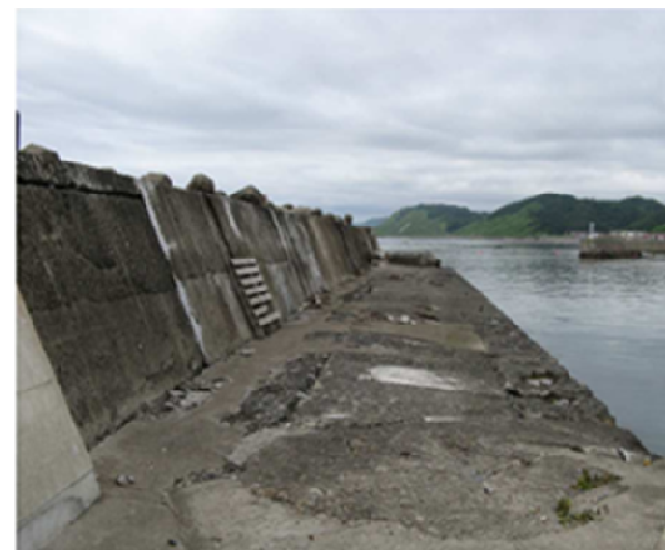

図-2 胸壁の外観

て，ひび割れ幅が異なる複数地点でひび割れ幅とひび割 れ深さを測定した. 現地調査を行った海岸施設は3施設, 合計6スパンである.

\section{(2) ひび割れ幅とひび割れ深さの関係}

本論文では，耐力に大きな影響を与えると考えられる ひひ割れ深さを目視等で容易に測定可能なパラメータで 推定することを試みる．調査した胸壁のひび割れ幅とひ び割れ深さの関係を図-3に示す. 線形回帰分析を行った 結果，相関係数が0.679であった。したがって，ひび割 れ幅とひび割れ深さの両者においては，いくらかの相関 があることがわかった。これより，ひび割れ深さを推定 する際,ひひ割れ幅は重要な指標となり得ると考えられ る. 実務上，ひひ割れ深さを測定しようとすると，特別 な装置と技術が必要であり，簡便に行えるわけではない. そのため，ひび割れ深さをひび割れ幅などの容易に測定 できるパラメータで推定することができれば，実務上非 常に有意義であると考えられる。しかしながら，ひび割 れ幅のみを指標としてひび割れ深さを推定することは, 上記のように両者間の相関係数が 0.7 程度であることか

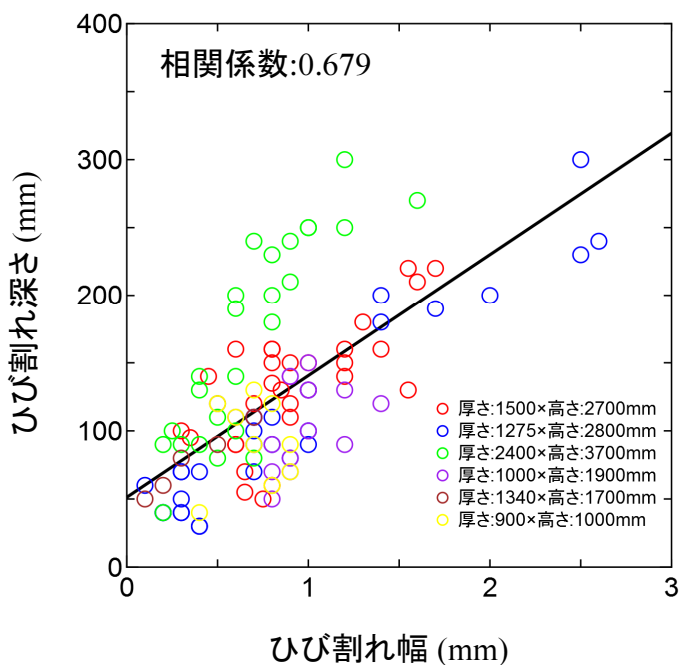

図-3 ひび割れ幅とひび割れ深さの関係

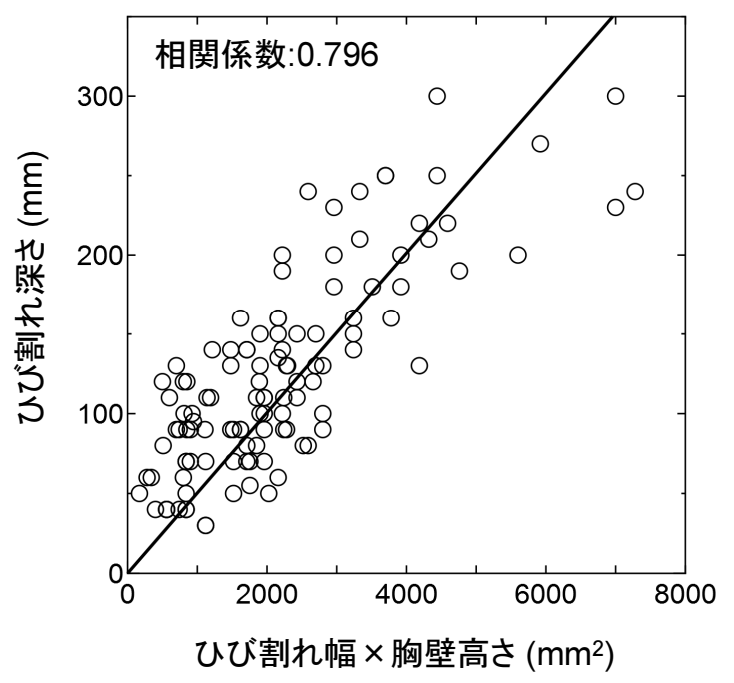

図-4 ひび割れ幅×胸壁高さとひび割れ深さの関係

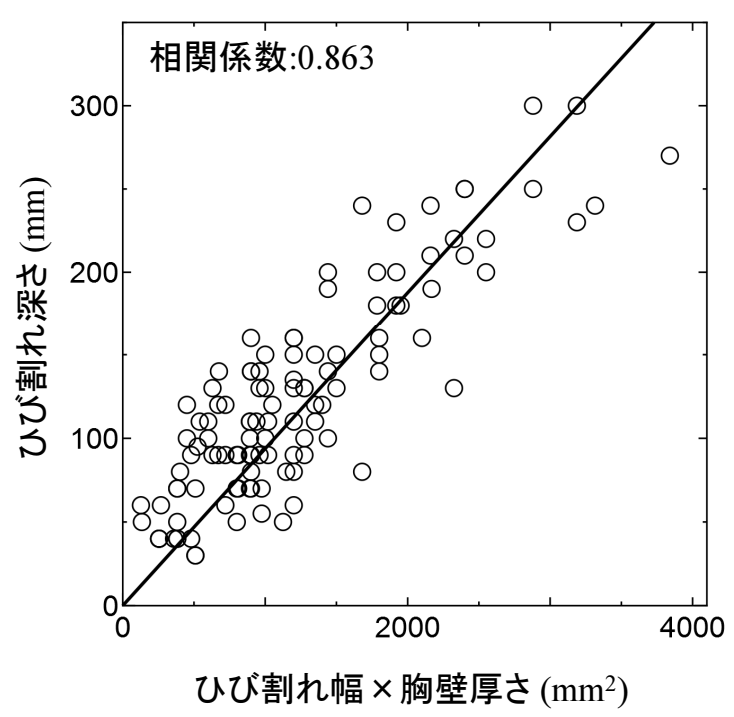

図-5 ひび割れ幅 $\times$ 胸壁厚さとひび割れ深さの関係 


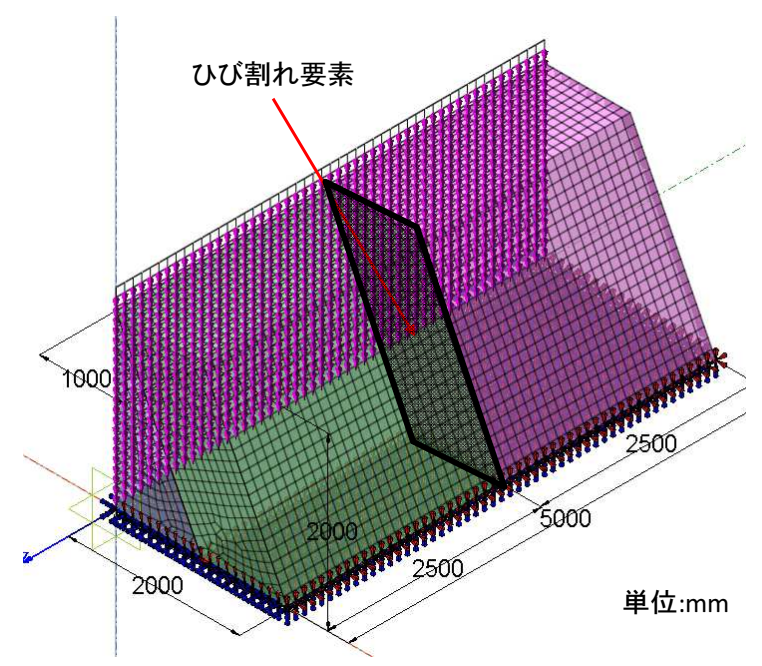

図-6 胸壁の構造解析モデル (Model 1)

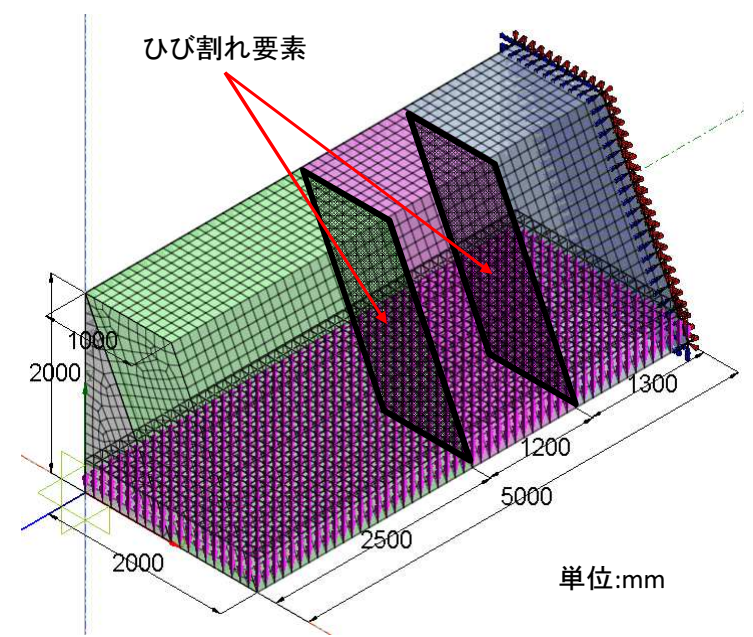

図-7＼cjkstart胸壁の構造解析モデル(Model2)

ら，推定誤差が大きくなる眯念がある．また，同図から 構造物の寸法が大きい場合，同じひび割れ幅でもひび割 れ深さが大きくなる傾向が見られた，そのため，胸壁の 寸法がひび割れ深さの推定に与える影響を考慮する必要 がある.

\section{（3）胸壁寸法の影響}

ひび割れ深さの推定誤差に関して，本論文では，胸壁 の寸法の影響を検討した．胸壁の寸法として，高さ $H$, 厚さB（本論文においては，胸壁の上辺厚さと下辺厚さ の平均值），横幅 $W$ を考える.

ひび割れ幅×胸壁高さとひび割れ深さとの関係を図-4 に示す。これより，ひび割れ幅×胸壁高さとひび割れ深 さの相関係数が 0.796 となり，ある程度の相関を有して いることがわかった。

ひび割れ幅 $\times$ 胸壁厚さとひび割れ深さとの関係を図-5 に示す，これより，ひび割れ幅×胸壁厚さとひび割れ深 さの相関係数が 0.863 となり，強い相関を有しているこ
表-1 コンクリート部材の材料特性

\begin{tabular}{|c|c|}
\hline 圧縮強度 $f_{c}\left(\mathrm{~N} / \mathrm{mm}^{2}\right)$ & 18 \\
\hline 引張強度 $f_{t}\left(\mathrm{~N} / \mathrm{mm}^{2}\right)$ & 1.8 \\
\hline ヤング係数 $\left(\mathrm{N} / \mathrm{mm}^{2}\right)$ & 25000 \\
\hline ポアソン比 & 0.15 \\
\hline 終局ひずみ $\varepsilon_{u}$ & 0.000311 \\
\hline せん断保有係数 $\beta$ & 0.2 \\
\hline
\end{tabular}

とがわかった．したがって，ひび割れ深さを推定には， ひび割れ幅のみでなく，構造物の寸法の影響が大きいこ とが確認された，そのため，今回の調查データの範囲内 においては，ひび割れ幅×胸壁厚さのひび割れ深さに対 寸る相関係数が 0.863 と大きいことから，本論文におい ては，ひび割れ幅×胸壁厚さでひび割れ深さを推定する 式(1)を提案する.

$$
D=A(w \cdot B)
$$

ここで,

$D:$ ひび割れ梁さ(mm)

$A$ : 回帰係数 $(0.0938)$,

$B$ : 胸壁厚さ $(\mathrm{mm})$

$w:$ び割れ幅(mm)

\section{3. 鉛直ひび割れを有する胸壁の構造解析}

\section{(1) 概要}

本解析では，初期状態として鉛直ひび割れを有する胸 壁の構造解析モデルを作成し, 非線形有限要素解析を行 った，構造解析モデルパターンとして，ひび割れ深さお よび本数を変化させた. 荷重載荷パターンとしては, 波 力を模擬したものおよび不同沈下を模擬したものとした.

\section{(2) 胸壁の構造解析モデル}

ひび割れを有する胸壁の構造解析モデル(Model 1)を図6に示す。コンクリート部材を6面体ソリッド要素 $(100 \mathrm{~mm} \times 100 \mathrm{~mm} \times 100 \mathrm{~mm})$ でモデル化した．ひび割れは， ひび割れ挿入地点に界面要素を挿入することで表現し, 要素挿入深さを変化させることでひび割れ深さの変化を 再現した．また，ひび割れ本数による影響を考慮するた めに設定した，ひび割れを2本有する胸壁の構造解析モ デル(Model2)を図-7に示す.

コンクリート部材要素の材料特性を表-1に示す，載荷 中に新たに発生するコンクリートのひび割れの進展につ いては, 分散ひび割れモデルのにより表現した。引張軟 化挙動の開始に対し，線形応力カットモデルを採用した. ひび割れ発生に伴うひび割れ幅と引張応力の関係につい 


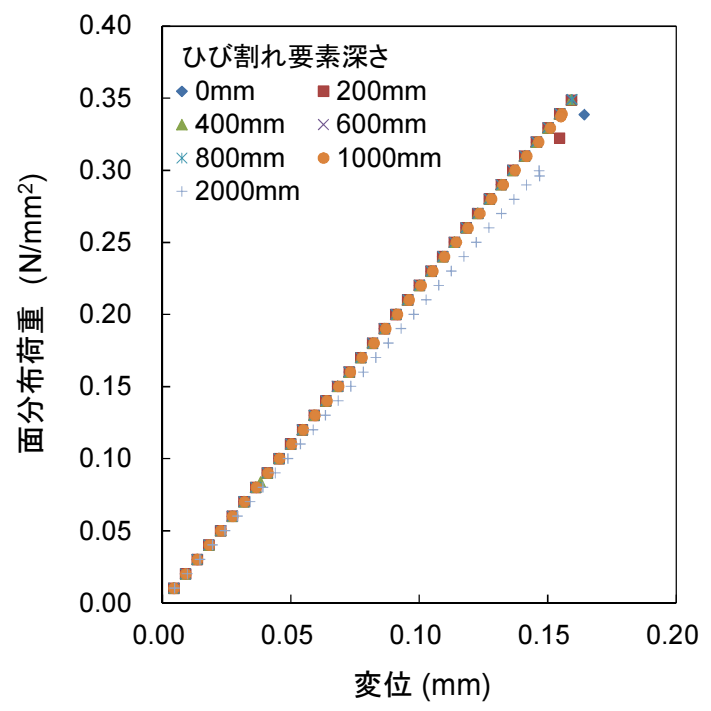

図-8 斜め入射での荷重一変位曲線(Model 1)

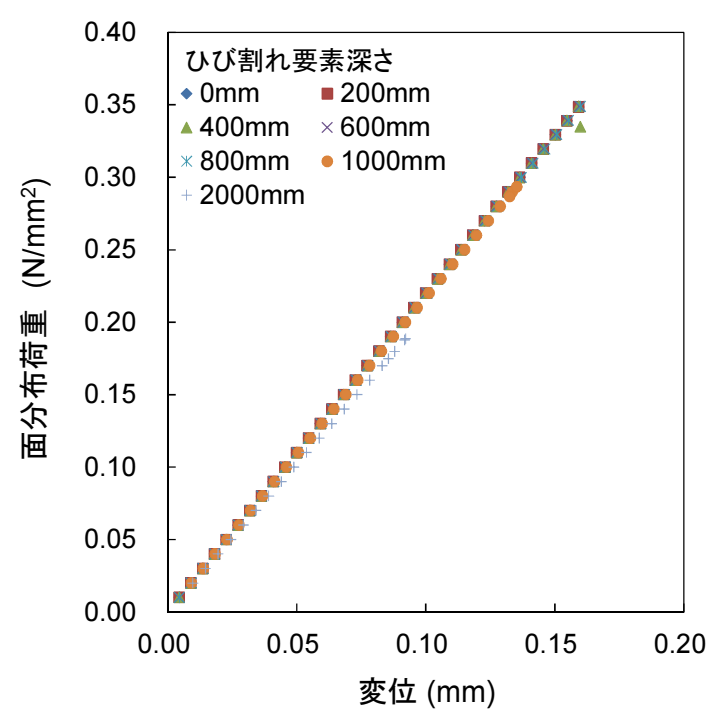

図-9 斜め入射での荷重一変位曲線(Model 2 )

ては線形引張軟化曲線を採用した。コンクリートのひび 割れ発生に伴いせん断岡性を $25 \%$ に低減した。 なお，初 期ひび割れの表現として用いた界面要素は，剛性および せん断伝達応力を概ね 20 としたため，骨材のか夕合わせ によるせん断抵抗については考慮していない，修正ニュ ートンラプソン法わを用いて収束計算を行い，収束判定 にはエネルギーノルムを用いた。

\section{(3) 斜め入射波力による構造解析}

外力として, 波力を模擬した荷重を与えた際の解析を 行った. 荷重載荷条件としては, 胸壁前面に垂直方向に 与えた場合, ひび割れを導入しても2次元解析と同等と なることから而力低下が確認できなかったため, 構造解 析モデル前面に斜め45度方向に面分布荷重を与えた. 境 界条件としては，モデル底面を完全に固定とした．ひび

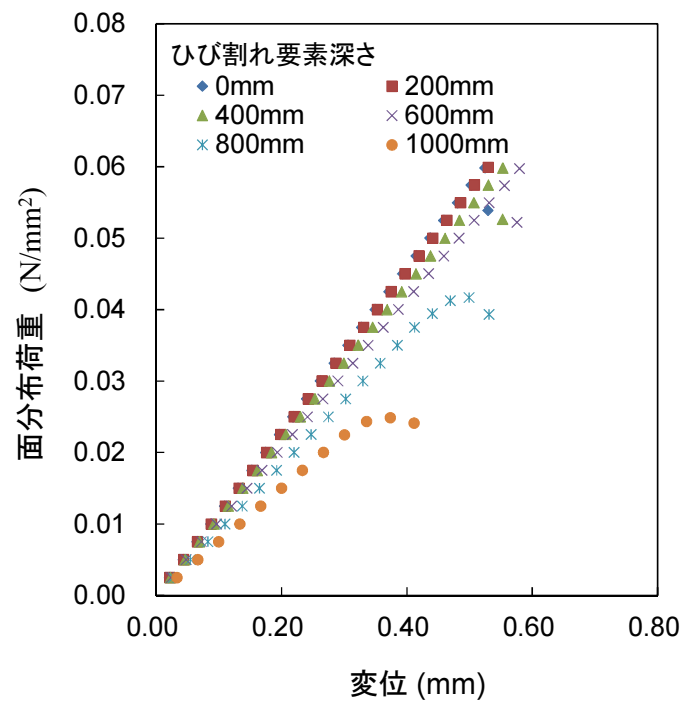

図-10 不同沈下での荷重一変位曲線(Model 1)

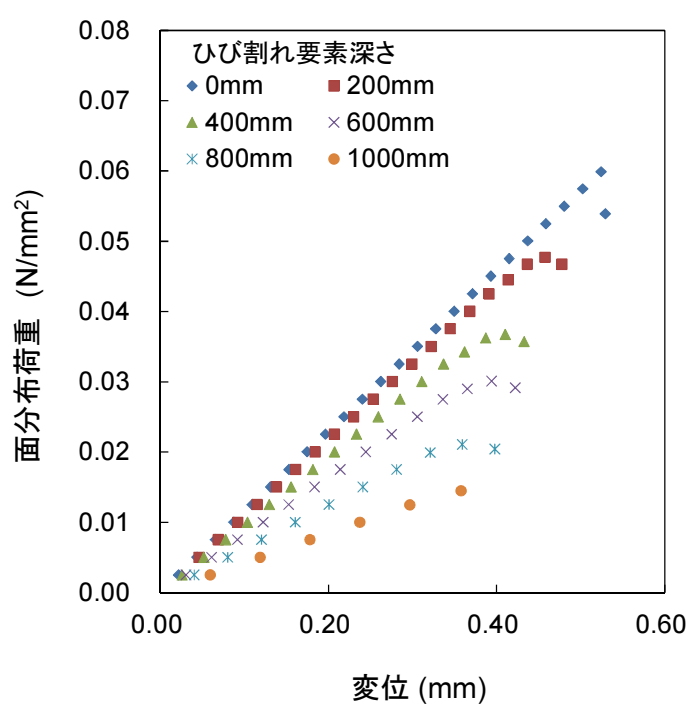

図-11 不同沈下での荷重一変位曲線(Model2)

割れの界面要素深さを $0 \mathrm{~mm}, 200 \mathrm{~mm}, 400 \mathrm{~mm}, 600 \mathrm{~mm}$, $800 \mathrm{~mm}, 1000 \mathrm{~mm}, 2000 \mathrm{~mm}$ と変化させて解析行い, 破壊 に至るまでの最大荷重（ピーク荷重）を求めた。（図-6 参照）。なお，界面要素は斜めに平行四辺形で挿入した。 そのため,ひび割れの界面要素深さは平行四辺形の奥行 辺の長さである.

Model 1の荷重一変位曲線を図-8に示す，ひび割れ界面 要素深さが $0 \mathrm{~mm}, 200 \mathrm{~mm}, 400 \mathrm{~mm}, 600 \mathrm{~mm}, 800 \mathrm{~mm}$ 場 合，荷重・変位曲線は概ね同等であった。また，ひび割 れの増加に伴う, ピーク荷重およひ岡性の低下は見られ なかった。しかしながら, $1000 \mathrm{~mm} て ゙ は 0 \mathrm{~mm} と$ 比較する と3\%程度のピーク荷重の低下が見らた。 また, 胸壁に 貫通ひび割れが発生している2000 mmでは，0mmと比較 すると 14\%程度のピーク荷重の低下および7\%程度の剛 性の低下が見られた。 
Model 2の荷重一変位曲線を図-9に示す。これより, Model 1 と同様に，ひび割れ界面要素深さが $0 \mathrm{~mm} ， 200 \mathrm{~mm}$, $400 \mathrm{~mm}, 600 \mathrm{~mm}, 800 \mathrm{~mm}$ の場合，荷重一変位曲線は概ね 同等であり，ひび割れ増加に伴うピーク荷重および剛性 の低下は見られなかった。しかしながら，1000mmでは $0 \mathrm{~mm}$ と比較すると $16 \%$ 程度のピーク荷重の低下が見らた. また，胸壁に貫通ひび割れが発生している2000mmでは $0 \mathrm{~mm}$ と比較すると $46 \%$ 程度のピーク荷重の低下および 7\%程度の剛性の低下が見られた. Model 1と比較し, Model 2においてはひび割れ要素深さの増加に伴うピー ク荷重低下量は大きかった，以上より，ひび割れ深さが 増加するに従いピーク荷重および岡性が低下することが わかった. さらに，胸壁に発生したひび割れ本数がピー ク荷重の低下に与える影響は大きく，ひび割れ深さが 1000mmにおいては，Model 1とModel 2ではピーク荷重低 下量に5倍程度の差異が生じた。

\section{(4) 不同沈下による構造解析}

不同沈下は底面に強制変位を与えて解析すべきである が，本研究では沈下の影響を簡便に検討するため，不同 沈下の作用を模擬した面分布荷重を構造解析モデル底面 に下向きに与えた．境界条件としては，モデルの片側側 面を固定とした。ひび割れの界面要素深さを $0 \mathrm{~mm}$,

$200 \mathrm{~mm}, 400 \mathrm{~mm}, 600 \mathrm{~mm}, 800 \mathrm{~mm}, 1000 \mathrm{~mm}$ と変化させ て解析を行い，破壊に至るまでの最大荷重（ピーク荷重） を求めた。（図-7参照）。

Model 1の荷重一変位曲線を図-10に示す。これより, ひび割れ要素深さが600mmまではピーク荷重の低下が見 られなかった. その後, 600mmを超えた時点からピーク 荷重の低下が見られ，1000mmの場合ではピーク荷重が $0 \mathrm{~mm}$ の場合と比較し $50 \%$ 以上低下した。 また，ひび割れ の要素深さが増加するに従い剛性が低下することがわか つた.

Model 2の荷重一変位曲線を図-11に示す.これより, ひび割れの要素深さが増加するに従い，ピーク荷重およ び剛性の低下が見られた. Model 1と比較すると, その 低下量が大きく，ひび割れ本数が構造性能に与える影響 が大きいことがわかった，以上より，本解析における条 件内においては，斜め入射波力および不同沈下のどちら を想定した場合でも，ひび割れ本数が増加することによ り，ピーク荷重および剛性の低下量が大きくなることが わかった。

\section{4. 無筋コンクリート海岸構造物の劣化度判定基 準の提案}

解析結果より, 既にひび割れを有した胸壁の荷重一変 位曲線は，荷重に伴うひび割れが発生するまでは概ね線

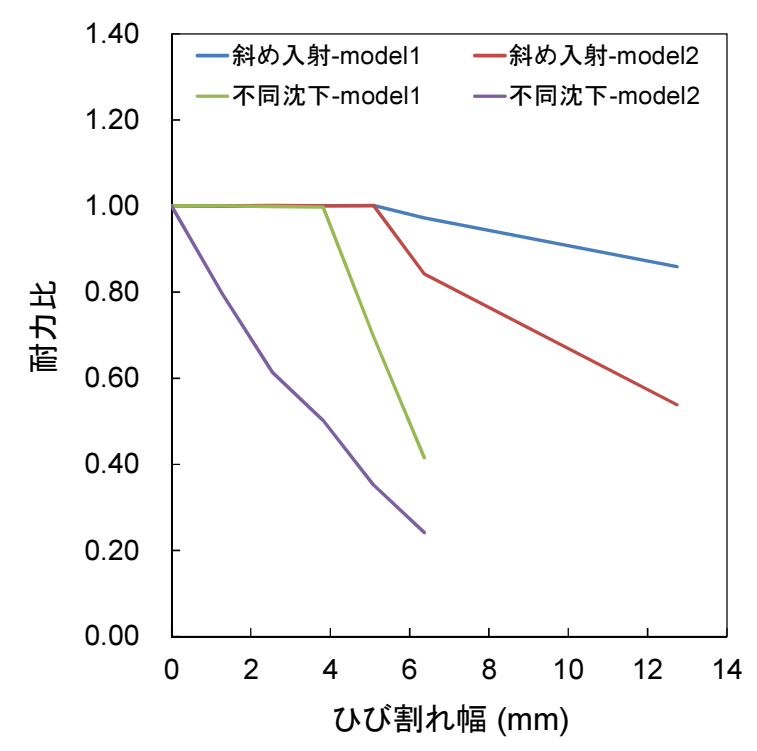

図-12 ひび割れ幅と而力比の関係

形の挙動を示し，その後，コンクリート要素に分散ひび 割れが発生すると同時に急速に破壊が進行することがわ かった. そのため, 本論文では, 荷重一変位曲線におけ るピーク荷重を構造物の耐力として定義した.

3章ではひび割れ深さの変化とともに耐力の低下を求 めた. 式(1)を用いてひび割れ梁さをひび割れ幅に逆算 することで，ひび割れ幅と耐力低下の関係を得た．なお， 式(1)のひび割れ深さは測定面から垂直距離のひび割れ 深さであるので, ひび割れ要素深さを垂直距離のひび割 れ深さに変換した後ひび割れ幅に変換した．図-12にひ び割れ幅とひび割れが発生していないモデルでの耐力を 1とした場合の耐力比の関係を示寸．これより，斜め入 射波力を想定した場合の耐力低下は，ひび割れ幅が7mm では, Model 1において耐力が96\%程度, Model 2において 耐力が $80 \%$ 程度になった。 不同沈下を想定した場合,

Model 1ではひび割れ幅が4mmを超えた時点で, 耐力が 低下寸ることがわかった. Model 2においては，さらに ひび割れ幅が小さい段階で耐力が低下寸ることがわかっ た.したがって，斜め入射波力に対して，ひび割れ幅の 増加による耐力の減少量は, 不同沈下と比較して小さい ことがわかった。つまり，ひび割れ幅が同じでも，不同 沈下を想定した場合, 無筋コンクリート構造構造物の耐 力に与える影響は大きいと推察される. また, Model 1 とModel 2を比較した場合，ひび割れを2本有したModel 2 において耐力低下量が大きくなった。したがって, 無筋 コンクリート海岸構造物における劣化度判定を行う際, ひび割れの幅, 長さだけではなく発生しているひび割れ の本数も考慮に入れて判断しなければならないことがわ かった.

以上より, 目視点検で簡易に測定可能なひび割れ幅と 
表-2 本論文で提案する劣化度判定基準

\begin{tabular}{|c|c|}
\hline 劣化度 & 判定基準 \\
\hline$d$ & 変状なし \\
\hline$c$ & ひび割れ幅4mm未満 \\
\hline \multirow{2}{*}{$b$} & ひび割れ幅4mm以上6mm未満 \\
\cline { 2 - 3 } & ひび割れが2本 \\
\hline \multirow{3}{*}{$a$} & ひび割れ幅6mm以上 \\
\cline { 2 - 3 } & 貫通ひび割れが発生している \\
\cline { 2 - 3 } & ひび割れ幅4mm以上のひび割れが2本 \\
\hline
\end{tabular}

ひび割れは胸壁の鉛直方向に生じるものを対象

耐力低下の関係を示すことができたこれより，現行の 無筋コンクリート海岸構造物の劣化度判定基準 ${ }^{8}$ が4段階 評価 $(d \sim a)$ であることを踏襲し，本論文での知見から提 案する新しい劣化度判定基準も4段階評価とし, 表-2に 提案した．劣化度 $d$ は施設に変状が生じていないとした。 劣化度 に耐力の低下が見られなかったひび割れ幅 $4 \mathrm{~mm}$ 未満とし た. 劣化度 $a$ は不同沈下を想定した場合にひび割れ幅が $6 \mathrm{~mm}$ 程度で耐力が $50 \%$ 以下になり，さらにひび割れが2 本においては，ひび割れ幅が $4 \mathrm{~mm}$ 程度で耐力が50\%を下 回ることより設定した．なお，この基準は，鉛直方向の ひび割れを対象としたひび割れ幅およびひび割れ本数を 劣化度判定の指標としている.

\section{5. まとめ}

本論文において得られた結論は以下のとおりである.

1）無筋コンクリート海岸構造物である胸壁に発生して いたひび割れの現地調査を行った結果，ひび割れ梁 さとひび割れ幅には強い相関があることがわかった。

2）現地調查結果を確率統計手法で整理した結果，ひび 割れ幅と胸壁厚さからひび割れ深さを推定する式を 提案した.

3）ひび割れを有した構造解析モデルを作成し，不同沈 下および波力を想定した非線形有限要素解析を行っ た結果，ひび割れ深さと構造物の耐力との関係を示

$$
\text { した. }
$$

4)ひび割れ性状と胸壁の耐力低下の関係を明らかとし， ひび割れ幅およびひび割れ本数を指標とする無筋コ ンクリート胸壁の劣化度判定基準を新たに提案した。 今後, データ蓄積および類似の構造物を対象とした調 査を継続して行い, ひび割れ深さの推定式の精度および 信頼性を向上させたいと考えている，さらに，無筋コン クリートを対象としたひび割れ面での骨材かみ合わせに よるせん断伝達を考慮することで, 構造解析モデルの精 緻化をはかり，精度の高い構造性能評価を行う予定であ る.

謝辞 : 現地調査の実施に際して, （株）アルファ水工コ ンサルタンツ・吉野真史氏のご協力をいただきましたこ とに感謝申し上げます。

\section{参考文献}

1) 高橋宏直, 後藤文子, 横田弘：港湾施設の維持補 修・更新費の将来推定(2005), 国土技術政策総合研究 所資料, No.257, 2005.

2) 横田弘, 山内浩, 加藤絵万, 岩波光保: 既設栈橋の ライフサイクルシナリオに関する検討，港湾空港技 術研究所資料，No.1114，2005.

3) 加藤絵万, 岩波光保, 横田弘: 栈橋のライフサイク ルマネジメントシステムの構築に関する研究, 港湾 空港技術研究所報告, 第 48 巻, 第 2 号, 2009.

4) 日本コンクリート工学会 : 東日本大震災に関するコ ンクリート工学の面からの提言, 2012.

5) 首藤浩一, 日比紀夫, 岩野聡史, 極檀邦夫: 衝撃弾 性波法によるひび割れ深さ測定の基礎的研究, 土木 学会第 58 回年次学術講演会, V-394, 2003.

6) JIP テクノサイエンス株式会社 : DIANA9 ユーザーマ ニュアル日本語参考資料（材料ライブラリー）,2005.

7) JIP テクノサイエンス株式会社 : DIANA9 ユーザーマ ニュアル日本語参考資料（解析ライブラリー）,2005.

8) 農林水産省農村復興局防災課ほか：ライフサイクル マネジメントのための海岸保全維持管理マニュアル (案) , 2008 .

\section{STRUCTURAL PERFORMANCE ASSESSMENT OF UN-REINFORCED CONCRETE COASTAL STRUCTURES}

\section{Koichi FURUYA, Hiroshi YOKOTA and Katsufumi HASHIMOTO}

This paper discusses the methodology on performance assessment of un-reinforced concrete structures with cracks. Inspection on un-reinforced concrete coastal structures has been conducted to qunatitatively evaluate crack properties. The authors proposed an equation to estimate crack depths from their widths by the statistical analysis. Subsequently, an un-reinforced concrete parapet was modeled with various crack patterns by using the proposed equation considering the size of the structure. A finite element analysis was carried out to identify the relationship between crack patterns and structural performance of unreinforced parapet. As a result, a deterioration grading criterion based on the surface crack width and the size of structure was newly proposed for assessment of structural performance of un-reinforced concrete coastal structures. 